\title{
Polite Rituals in the Classroom Interaction
}

\author{
Murni Mahmud \\ Universitas Negeri Makassar \\ Makassar, Indonesia \\ murnimahmud@unm.ac.id
}

\begin{abstract}
This paper's main focus is to explore the expressions used by teachers in the class to show their politeness. The subject of this research is two English lecturers of Faculty of Languages and literature, State University of Makassar. To collect data, the teaching process of the two teachers were recorded, transcribed, and analyzed. The results of the research show that the two English teachers applied several ways of expressing politeness as their ritual in the class such as greetings, apologies, thanks, address terms, and requests.
\end{abstract}

\section{Keywords—classroom interaction; expression; politeness}

\section{INTRODUCTION}

Studies about politeness about English language teaching had been conducted recently on politeness in teacher-student interaction, asserted that politeness is 'an important aspect of student character building in classroom interaction [1]-[3].' Politeness had important roles in maintaining good communication in the class [2]. White states that 'the form of communication used in the classroom affects the content of the knowledge, which is mutually constructed by the teacher and students.' Politeness does promote the mutual understanding and harmonious relationship between teacher and students; politeness does enhance teaching and benefits the students; politeness does contribute to the effective interaction and friendly, lively atmosphere in EFL classroom [3]. Therefore, it is important for teachers and students as actors of the class to practice politeness during the learning and teaching process so that the ideas of transferring messages and knowledge can run smoothly.

In this paper, it is pointed out that politeness has an important role in the classroom settings. Teachers need to maintain good interaction such as their politeness so that the teaching process to learn the language may run smoothly and appropriately. For this purpose, a study was conducted on exploring the expressions used by teachers as their rituals to be polite in the classroom. The focus of this paper is on the exploration of the politeness expressions used by teachers as their rituals in the class.

\section{RESUlT AND DisCUSSION}

The following extracts show some expressions used by the two teachers as their rituals to be polite in the classroom.

Extract 1: Greetings and Apologies

L: "Assalamu alaikum Wr.Wb."

\author{
"peace be upon you." \\ S: "Waalaikumsalam Wr.Wb." \\ "peace be upon you too." \\ L: "Sorry for being late, because I saw your SMS a few \\ minutes ago, lforgot this class.
}

In the above extract of conversation, the teacher (L) used expressions which aimed to show his politeness in the class. The excerpts from recording above were taken at the beginning of the class, and the teacher was about to start the class. The teacher said, "Assalamu Alaikum" (peace be upon you) to start the lesson, which is a greeting for Muslim people. That sort of greeting is commonly used since teachers and students are mostly Muslim. Very few of students as well as teachers in the university who are not Muslim, and therefore, this kind of greeting was regularly used in the class. In extract 1 , after the teacher said the greeting, he followed by saying apology, that was by saying "Sorry for being late." This apologizing expression was also commonly used by the teacher, especially when explaining the reasons for coming late to the class. The same case can be seen in the following extract:

\section{Extract 2: Greeting in the class}

L: "assalamualaikum warahmatullahi wabarakatuh..!" "piece be upon you"

S : "waalaikumsalam warahmatullahi wabarakatuh" "peace be upon you too."

L: "we open the program with basmalah together." "we open the program [the class] by reciting "Basmalah."

S: "bismillahirrahmanirrahim..." "in the Name of Allah"

L: "ok."

$$
\text { "okey" }
$$

In extract 2 above, the teacher used the greeting "assalamualaikum warahmatullahi wabarakatuh". After saying the greeting, the teacher indeed asked students to recite "Basmalah." This expression was also derived from Islamic teaching in which to start the activities, Muslim people are recommended to recite "Basmalah" (in the Name of Allah).

The two extracts above are examples of expressions used by teachers to be polite in the class. These expressions were mostly found by most of the teachers as their ritual to be polite. Those expressions are intended to create a harmonious situation in the class which is good to begin the teaching 
process. In extract 1, for example, the greeting and the apology were used to minimize the condition in the class caused by being late. Of course, teachers and students are subject to the rules in the teaching process, in which one of them is by coming on time to the class. In extract 2 , the greeting and the reciting of Basmalah made the situation more harmonious especially seen from Islamic context.

\section{Extract 3: Addressing each other}

$L$ : “disitu pekerjaannya saya cuma koreksi jawaban yang kamu tulis jawaban saya tidak check pertanyaannya..tapi..."

(there, my task is only to correct the answers you had written. I did not check the questions, but...)

$S$ : "iya Mam itu yang jawabannya"

(yes, Mam, that is the answer)

In extract 3 above, the teacher was explaining the learning mechanism in the class. She used an sddress term "kamu" (you) to address her students in the class. Conversely, her students used an address term "Mam". From this conversation, it can be seen that each speaker was trying to use suitable address term. The teacher is possible to use that informal address term since her position is higher than students. Conversely, her students were subject to use that polite address term as the way to show their politeness to their teachers.

\section{Extract 4: Talking a Korean movie}

$L$ : "ya ada juga sih ya ada juga yang teman-teman dosen yang muda-muda tergila-gila juga Korea, sampai ditawari saya, Pak Hasbi gak mau copy filenya, episode 1 sampai 16, ah gak deh. Tapi sekilas saya lihat kemarin ada hubungannya dengan konflik Korea Utara dan Korea Selatan ya?",

(yes ther is also, there are some friends who are still young, who like Korean movie very much. Indeed, they asked me to copy the file, episode 1 to 16 . I said no. but at a glance, I saw it was about war conflict in Korea between North Korea and South Korea).

$S$ : "ada Sir, ada"

(there is, Sir)

L : "sekilas ku lihat, militer kan?"

(at a glance, that was about military case, isn't it?)

$S$ : "iya. Sir"

(yes, Sir).

In extract 4 above, the teacher was explaining about a Korean movie which was still related to the study of English literature in the class. In the conversation, the students also used an address term "Sir" to address their teacher in the class. This also show the use of polite address terms in the class.

From extract 3 and 4 above, the use of address terms can be used as the ways to be polite in the class. The position of teachers and students determine the ways they used address terms in the class.

\section{Extract 5: Request and Questions}

L : "The one man at the back, please. Any questions so far? Okay...so far so good. Salah satu kekurangan dalam menggunakan bahasa yaitu tidak mengembangkan kalimat itu sendiri. Maka dari itu diperlukan latihan. Untuk materi yang ini kita kerjakan di pertemuan berikutnya ya.. Okay, that is over. Okay, you can change some part of sentences when you know how to put it in the sentence's contraction. Okay, kesimpulan. Kesimpulan pertama silahkan. Kesimpulan dari apa yang telah dipelajari hari ini.

(The one man at the back, please. Any questions so far? Okay...so far so good. One of the weaknesses in using a language is that not developing the sentence itself. That's why it needs practising. For this material, we are going to do this in the next meeting. Okay. That is over. Okay, you can change some part of sentences when you know how to put it in the sentence's contraction. Okay, the conclusion. The first conclusion, please. The conclusion for today's lesson)

S :"Oh.."

In extract 5 above, the teacher was explaining about one material in the class. During the process, she was asking questions and requesting students to do the activities in the class. In order to be polite, the teacher used the expression "please' to soften her instruction.

The above discussion shows that topics of politeness remain important in every context of situation. The two teachers who had been recorded in the class applied some expressions to be polite as their rituals in order to maintain the good flow of the conversation. This shows that classroom as the setting of communication especially between teachers and students demand polite expressions. One of the important findings above is about the ways of expressing politeness by the students. Based on the recording above, teachers used several expressions to be polite as their rituals to start and conduct the teaching process. Some of them are the use of greetings, apologies, address terms, questions and requests. This finding is in line with the study that some expressions used by teachers in the class to express their politeness which became the ways to integrate the power and the need to maintain solidarity in the class [4].

Therefore, it is important for teachers and students as actors of the class to practice politeness during the learning and teaching process in order that the ideas of transferring messages and knowledge can run smoothly [1]-[3]. This finding is in line Teachers and students as actors in the class are main players to create good communication in the class, which can be reached by applying politeness in the two parts. Disruptive behaviours in the class may ruin the process of interaction which can also affect the success in achieving the goals of learning and teaching process.

This finding also confirms that the notion of politeness and classroom interaction is relevant in language learning, particularly the teaching of English as a foreign language. It should be noted that students learning English as a second language needs much effort to achieve the success. Learning a second language is 'a long and complex undertaking' [5]. It is suggested that a person learning a language should struggle upon the confines of acquiring 'new language, new culture, 
and new way of thinking, feeling, and acting'. Therefore, many factors are needed covering 'the total commitment, total response, and total physical, intellectual, and emotional response' [5]. Politeness of teachers as well as students are necessary to maintain good classroom interaction.

\section{CONCLUSION}

This paper has explored the politeness expressions used by teachers in the classroom interaction. Some strategies were used by the teachers such as greetings, apology, questions, and request), and address terms. This finding is worthy of discussion as the existing phenomenon of politeness in different culture and in different settings. Politeness remains important in every facet of human's life. This finding, however, still needs further studies to explore more practices of politeness in the classroom setting and its relationship to the students' achievement.

\section{REFERENCES}

[1] S. Senowarsito, "Politeness strategies in teacher-student interaction in an EFL classroom context,” TEFLIN J., vol. 24, no. 1, pp. 82-96, 2013.

[2] J. J. White, "The Power of Politeness in the Classroom: Cultural Codes that Create and Constrain Knowledge Construction.," J. Curric. Superv., vol. 4, no. 4, pp. 298-321, 1989.

[3] X. Jiang, "A case study of teacher's politeness in EFL class," J. Lang. Teach. Res., vol. 1, no. 5, pp. 651-655, 2010.

[4] M. Mahmud, "TEACHERS 'RITUALS TO BE POLITE IN THE CLASSROOM: CONTESTING POWER AND SOLIDARITY.," J. Lang. Lit., vol. 5, no. 2, 2014.

[5] H. D. Brown and 吳一安, “Principles of language learning and teaching," 2000. 